\title{
STRUCTURE OF COSTS AND EXPENDITURES IN AGRO TECHNOLOGIES OF DIFFERENT INTENSITY LEVELS
}

\author{
Andrei Valerievich Gostev ${ }^{1^{*}}$ Alexey Ivanovich Pykhtin ${ }^{2}$ \\ ${ }^{1}$ All-Russia Research Institute of Arable Farming and Soil Erosion Control, Kursk, Russia \\ ${ }^{2}$ Southwest State University, Kursk, Russia
}

As a result of the analysis and generalization of the obtained data average structures of prime costs and expenditures in grain crop cultivation technologies were defined. They testify the nonequivalence of the impact of different techniques on the prime costs and expenditures depending on the application of extensive, basic, and intensive agro technologies. Thus, for extensive grain cultivation technologies the most costly in terms of economy and energy expenditures is sowing, which is connected mainly with heavy seeding of most small grain crops. Therefore, the main trend in cost-effective use of resources for extensive grain crop cultivation technologies is application of resource saving elements while sowing. Another way for the cost-effective use of resources can be the reduction of used recourses during harvesting and soil preparation. Using basic grain crop cultivation technologies in addition to the already mentioned common for extensive technologies trends in resource-saving scientifically grounded use of the system of fertilizers and crop protection products can be involved; they amount to 1/3-1/2 of overall costs and expenditures in agro technologies of this type. In intensive agro technologies the proportion of costs of plant protection products and fertilizers further increases and the proportion of costs for sowing decreases. Therefore, the main trend in intensive grain crops cultivation is scientifically-grounded use of fertilizers and protection products. Hence, with the increase of the technology intensification level the impact of such agro technological elements as tillage, sowing and harvesting decreases. It is connected mostly with the fact that for extensive technologies these elements are the most costly ones and correspondingly, their values significantly impact the total values of the overall costs of the applied technologies. On the other hand, along with the increase of the technology intensity level the role of mineral fertilizers and plant protection products increases since these elements facilitate quantitative and qualitative improvement of the cultivated crops capacity.

Key words: Costs, Technology, Cultivation, Crops

\section{INTRODUCTION}

Improvement of agriculture efficiency, its competitive ability in world and national markets is an important task. This problem cannot be solved without new agro technologies and technical modernization of crop production [01]. In modern agriculture different in terms of intensity technologies can be applied in field crop cultivation. One of the most important issues of the selection of technology intensity is the availability of essential for technology implementation material and technical resources. In case of the lack of resources, application of intensive technologies is useless since lack of at least one of such resources results in the decrease of their efficiency [02]. It should be noted that at the modern stage of agriculture, extensive and basic grain crops cultivation technologies are mostly applied, with all their advantages and disadvantages. Therefore, the issues of their optimal use are quite topical [03]. Besides, taking into consideration the diversity of climatic and natural conditions of the Russian Federation, it can be mentioned that there are a lot of efficient means for successful reduction of the amount of used resources in crops cultivation, however, due to different contribution into the cost items of agro technologies, resource-saving values can be significant, therefore it is necessary to have a clear understanding of the structure of costs and energy expenditures regarding used extensive, basic and intensive technologies.

As is known, there are two approaches to the definition of the efficiency of the applied technology and assessment of the degree of its resource saving ability: an economic approach [04] and an energy approach [05]. The negative aspect of the economic assessment is its high dependency on the pricing mechanism connected with constantly changing currency exchange rates, machinery costs, and cost of pesticides, fertilizers and grains. In its turn, the calculation of energy estimate is quite complicated and requires a lot of reference data. Therefore, it is more feasible to consider resource saving to be an integrated process, facilitating reduction of not only economic expenditures but also energy expenditures. Calculating the costs in the agricultural technologies under study, we relied on the price level prevailing in 2016. The analysis of technologies of cultivation of grain crops was based on 97 agro-technologies for cultivation of 8 grain crops presented in the Register of Technologies of grain crops for the Central Black Soil region [06, 07].

\section{EXTENSIVE TECHNOLOGIES}

Extensive technologies are based on the use of natural soil fertility without fertilizers and other chemicals or with 
very limited use of them. Therefore, the main expenditure items (according to Table 1) are accounted for basic tillage, sowing and harvesting.

Based on the information presented in Table 1, for extensive technologies of cultivation of grain crops the most cost effective approach in terms of the economy and energy expenditure is sowing activities. This is mainly due to the fact that most grain crops have a high seeding rate and require a large amount of seeds. Therefore, the main focus for resource saving in extensive technologies of grain crops cultivation is on the implementation of resource-saving elements in seeding. Other ways for resource-saving for such technologies can be the reduction of the resources used during harvesting and basic tillage.

\section{BASIC TYPE TECHNOLOGIES}

Basic type technologies imply creating more comfortable abiotic conditions for crops growing, including the use of optimal amount of fertilizers, application of chemical means of plant protection closely connected with the thresholds of harmfulness of weeds, pests and diseases. Accordingly, the inclusion of these activities into the technology of cultivation requires certain expenditures (Table 2).

In contrast to the energy assessment, while calculating costs, unit impact of plant protection products increases due to their high cost.

As can be seen from Table 2, using basic technologies of cultivation of grain crops in addition to the already mentioned areas of resource efficiency common for extensive technologies, a scientifically grounded application of fertilizers and plant protections products, which account to one-third -a half of total costs for technologies of this type can be included.

Table 1: Allocation of costs and expenditures in grain crop extensive cultivation (on a 1 ha basis)

\begin{tabular}{|c|c|c|c|c|}
\hline \multirow{2}{*}{$\begin{array}{c}\text { Technology } \\
\text { element }\end{array}$} & $\begin{array}{c}\text { Energy } \\
\text { expenditures, MJ }\end{array}$ & $\begin{array}{c}\text { Contribution to the } \\
\text { total energy } \\
\text { intensity, } \%\end{array}$ & $\begin{array}{c}\text { Costs, Russian } \\
\text { rubles } \\
\text { (57 RUR = 1 USD) }\end{array}$ & $\begin{array}{c}\text { Contribution to the } \\
\text { total technology } \\
\text { cash costs \% }\end{array}$ \\
\hline Tillage & $350-700$ & $5-15$ & $300-900$ & $5-20$ \\
\hline Fertilizers & 0 & 0 & 0 & 0 \\
\hline Pre-sowing tillage & $50-250$ & $0-5$ & $150-400$ & $0-10$ \\
\hline Sowing & $2000-5000$ & $45-75$ & $2000-4500$ & $50-70$ \\
\hline Pesticides & 0 & 0 & 0 & 0 \\
\hline Harvesting & $450-1300$ & $5-30$ & $500-700$ & $10-20$ \\
\hline Other & $100-750$ & $0-15$ & $100-700$ & $0-15$ \\
\hline
\end{tabular}

Table 2: Allocation of costs and expenditures in grain crops basic cultivation (on a 1 ha basis)

\begin{tabular}{|c|c|c|c|c|}
\hline \multirow{2}{*}{$\begin{array}{c}\text { Technology } \\
\text { element }\end{array}$} & $\begin{array}{c}\text { Energy } \\
\text { expenditures, MJ }\end{array}$ & $\begin{array}{c}\text { Contribution to the } \\
\text { total energy } \\
\text { intensity, } \%\end{array}$ & $\begin{array}{c}\text { Costs, Russian } \\
\text { rubles } \\
\text { (57 RUR =1 USD) }\end{array}$ & $\begin{array}{c}\text { Contribution to the } \\
\text { total technology } \\
\text { cash costs \% }\end{array}$ \\
\hline Tillage & $800-1250$ & $5-15$ & $500-900$ & $5-10$ \\
\hline Fertilizers & $800-10000$ & $10-55$ & $1000-10500$ & $10-60$ \\
\hline Pre-sowing tillage & $100-350$ & $0-5$ & $150-400$ & $0-5$ \\
\hline Sowing & $2500-5500$ & $20-60$ & $1500-4500$ & $10-50$ \\
\hline Pesticides & $150-1050$ & $5-10$ & $1500-4000$ & $15-35$ \\
\hline Harvesting & $800-1400$ & $5-20$ & $500-650$ & $5-10$ \\
\hline Other & $200-1100$ & $0-10$ & $100-800$ & $0-10$ \\
\hline
\end{tabular}




\section{INTENSIVE AGRICULTURAL TECHNOLOGIES}

Intensive agricultural technologies imply the growing influence of crop protection products and fertilizer systems, against which the effects of the system of tillage smooth over (Table 3).

Similar to the situation with basic technologies, plant protection products have a multi-faceted contribution to the overall costs and expenditures depending on the method of their calculation.

In the intensive agricultural technologies the proportion of expenditures for protection products and fertilizers increases even more, and expenditures for sowing decreases. Therefore, the main trend in intensive technologies of grain crops cultivation is a science-based application of fertilizers and plant protection products.

Thus, along with the increase of the level of technology intensification the influence of such elements of agricul- tural technologies as basic tillage, sowing and harvesting decreases. It is connected with the fact that for extensive technology, these elements are the most cost-intensive and, accordingly, their values strongly influence the final values of the total costs of the applied technologies. On the other hand, along with the increase of the technology intensive level, the role of mineral fertilizers and plant protection products increases, as these elements contribute to the qualitative and quantitative productivity of cultivated crops.

Due to the fact that when calculating energy and economic expenditures, we obtained similar data on the contributions of individual agro-technological elements; we compared them against each other and obtained the following generalization (Table 4).

Table 3: Allocation of costs and expenditures in grain crop intensive cultivation (on a 1 ha basis)

\begin{tabular}{|c|c|c|c|c|}
\hline \multirow{2}{*}{$\begin{array}{c}\text { Technology } \\
\text { element }\end{array}$} & \multicolumn{2}{|c|}{ Energy expenditures } & \multicolumn{2}{c|}{ Economic expenditures } \\
\cline { 2 - 5 } & $\begin{array}{c}\text { Energy } \\
\text { expenditures, MJ }\end{array}$ & $\begin{array}{c}\text { Contribution to the } \\
\text { total energy } \\
\text { intensity, } \%\end{array}$ & $\begin{array}{c}\text { Costs, Russian } \\
\text { rubles } \\
\text { (57 RUR = 1 USD) }\end{array}$ & $\begin{array}{c}\text { Contribution to the } \\
\text { total technology } \\
\text { cash costs \% }\end{array}$ \\
\hline Tillage & $400-1000$ & $0-10$ & $250-600$ & $0-5$ \\
\hline Fertilizers & $1500-14000$ & $15-60$ & $2000-21000$ & $15-70$ \\
\hline Pre-sowing tillage & $50-500$ & $0-10$ & $150-400$ & $0-5$ \\
\hline Sowing & $1500-6000$ & $10-50$ & $1500-4000$ & $5-30$ \\
\hline Pesticides & $350-2000$ & $5-10$ & $1500-6500$ & $15-45$ \\
\hline Harvesting & $900-1500$ & $5-15$ & $600-750$ & $5-10$ \\
\hline Other & $250-1300$ & $0-10$ & $100-1000$ & $0-10$ \\
\hline
\end{tabular}

Table 4: Contribution of various technology elements of grain crops cultivation in terms of the integrated economy and energy approach

\begin{tabular}{|c|c|c|c|}
\hline \multirow{2}{*}{$\begin{array}{c}\text { Technology } \\
\text { element }\end{array}$} & \multicolumn{3}{|c|}{ Contribution to technology total costs and energy expenditures, \% } \\
\cline { 2 - 4 } & Extensive technologies & Basic technologies & Intensive technologies \\
\hline Basic tillage & $400-1000$ & $0-10$ & $250-600$ \\
\hline Fertilizers & $1500-14000$ & $15-60$ & $2000-21000$ \\
\hline Pre-sowing tillage & $50-500$ & $0-10$ & $150-400$ \\
\hline Sowing & $1500-6000$ & $10-50$ & $1500-4000$ \\
\hline Pesticides & $350-2000$ & $5-10$ & $1500-6500$ \\
\hline Harvesting & $900-1500$ & $5-15$ & $600-750$ \\
\hline Other & $250-1300$ & $0-10$ & $100-1000$ \\
\hline
\end{tabular}


Generalization of the obtained data allowed making the distribution of the main elements of technology of grain crops cultivation in accordance with the degree of their contribution to the overall technological costs (Table 5).

Table 5: Average distribution of basic elements of grain crop cultivation technologies in accordance with the contribution to total technological costs and expenditures

\begin{tabular}{|c|c|}
\hline Technology element & $\begin{array}{c}\text { Average contribution into } \\
\text { technology total costs, \% }\end{array}$ \\
\hline Sowing & 39 \\
\hline Fertilizers & 24 \\
\hline Pesticides & 12 \\
\hline Harvesting & 11 \\
\hline Basic tillage & 7 \\
\hline Other & 7 \\
\hline
\end{tabular}

As can be seen in the Table, the highest costs in agro-technologies of cultivation of grain crops are accounted for sowing, fertilizers, plant protection products and harvesting.

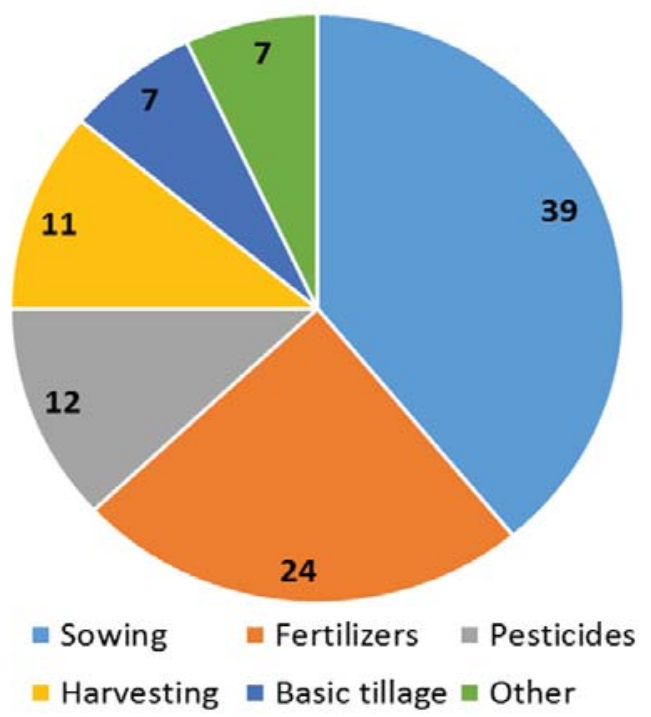

Figure 1: Distribution of basic elements of grain crops cultivation technologies in total technology costs and expenditures, \%

\section{CONCLUSIONS}

The data of the conducted research disprove a popular opinion stating that one of the most costly elements in agro technologies is basic soil preparation since its contribution according to energy and economic calculations is not more than $20 \%$ of the overall costs and expenditures. Soil preparation should not be completely opted out since the provided cost and expenditure structure does not consider the indirect impact of these elements.
It also should be mentioned that these data can be obtained provided quality performance of all techniques because poor performance even of one technique can undermine the technology as a whole and ultimately reduces to zero the effect of resource-saving techniques application.

\section{REFERENCES}

1. Cherkasov, G.N., Pykhtin, I.G., Gostev, A.V., \& etc, (2012). Teoreticheskiye osnovy formirovaniya agrotekhnologicheskoy politiki primeneniya nulevykh i poverkhnostnykh obrabotok pochvy pod zernovyye kultury dlya modernizatsii zemledeliya (Theoretical bases of formation of the agricultural technology policy the application of the zero and the surface treatments of the soil under cereals for modernization of agriculture). Kursk, Russia: VNIIZiZPE.

2. Pykhtin I.G., (2012). Produktivnost zernovyih kultur v zavisimosti ot intensivnosti tehnologiy (Productivity of grain crops depending on the intensity of technology). Zemledeliye, 8, 21-23.

3. Pykhtin, I.G., \& Gostev, A.V. (2007). The potential of individual technologies of grain crops cultivation on chernozems of CCZ (The potential of individual technologies of grain crops cultivation on chernozems of the Central black earth region). Dostizheniya nauki i tekhniki APK, 4, 40-42.

4. Orsik, L.S. (2001). Ekonomicheskaya effektivnost tekhnologiy vozdelyvaniya i uborki selskokhozyaystvennykh kultur (Economic efficiency of technologies of cultivation and harvesting of crops). Moscow, Russia: Efes.

5. Nikiforov, A.N. (1995). Metodika energeticheskogo analiza tekhnologicheskikh protsessov $\mathrm{v}$ selskokhozyaystvennom proizvodstve (The technique of energy analysis of technological processes in agricultural production). Moscow, Russia: VIM.

6. Cherkasov, G.N., Pykhtin, I.G., \& etc, (2013). Registr tekhnologiy vozdelyvaniya zernovykh kultur dlya Tsentralnogo Chernozemia (The case of the technologies of cultivation of grain crops for the Central Chernozem region). Kursk, Russia: VNIIZiZPE.

7. Gostev, A.V., Pykhtin, A.I., \& Nitchenko, L.B. The influence of technologies on productivity of grain crops in conditions of central region of Russia. $U$ : 17th International Multidisciplinary Scientific GeoConference SGEM 2017. 625-630.

Paper submitted: 24.10.2017.

Paper accepted: 30.11.2017.

This is an open access article distributed under the CC BY-NC-ND 4.0 terms and conditions. 